\title{
Discrimination of Genealogical Groups of Arabica Coffee by the Chemical Composition of the Beans
}

\author{
Larissa O. Fassio ${ }^{1}$, Marcelo R. Malta ${ }^{2}$, Gladyston R. Carvalho ${ }^{2}$, Antônio A. Pereira ${ }^{2}$, Ackson D. Silva ${ }^{2}$, \\ Gilberto R. Liska ${ }^{3}$, Adriene W. Pedrosa ${ }^{4}$, Vany P. Ferraz ${ }^{5} \&$ Rosemary G. F. A. Pereira ${ }^{6}$ \\ ${ }^{1}$ Fundação de Desenvolvimento do Cerrado Mineiro, Patrocínio, Brazil \\ ${ }^{2}$ Empresa de Pesquisa Agropecuária de Minas Gerais, Lavras, Brazil \\ ${ }^{3}$ Universidade Federal do Pampa, Itaqui, Brazil \\ ${ }^{4}$ Faculdade de engenharia de Sorocaba, Sorocaba, Brazil \\ ${ }^{5}$ Departamento de Química, Universidade Federal de Minas Gerais, Belo Horizonte, Brazil \\ ${ }^{6}$ Departamento de Ciência dos Alimentos, Universidade Federal de Lavras, Lavras, Brazil \\ Correspondence: Marcelo R. Malta, Empresa de Pesquisa Agropecuária de Minas Gerais, Campus da UFLA, P.O \\ Box 176, CEP: 37200-000, Lavras, Brazil. Tel: 55-35-3821-2231. E-mail: marcelomalta@epamig.br
}

Received: June 9, 2019 Accepted: July 27, $2019 \quad$ Online Published: September 30, 2019

doi:10.5539/jas.v11n16p141 URL: https://doi.org/10.5539/jas.v11n16p141

The research is financed by Consórcio Pesquisa Café, FAPEMIG, CNPq, CAPES.

\begin{abstract}
This work aimed to characterize and discriminate genealogical groups of coffee as to the chemical composition of the grains through the model created by PLS-DA method. 22 accessions of Coffea arabica, from the Active Germplasm Bank of Minas Gerais, were divided into groups according to the genealogical origin. Samples of ripe fruits were harvested selectively and processed by the wet method, to obtain pulped coffee beans, with $11 \%$ (b.u.) of water content. The raw beans were assessed as to the content of polyphenols, total sugars, total lipids, protein, caffeine, sucrose, and fatty acids. The data were submitted the chemometric analysis, PCA and PLS-DA. The results of PLS-DA identified the variables which most influence the classification of genealogical groups and possible chemical markers to accessions processed by the pulped method. The sucrose content was an important marker for the Exotic accession group. However, the content of polyphenols has been identified as a marker for the group Tymor Hybrid, and the caffeine for the bourbon group. The different fatty acids have been identified as markers for all genealogical groups, at different levels. The model PLS-DA is effective in discriminating genealogical groups from the chemical composition of the beans.
\end{abstract}

Keywords: Coffea arabica, chemical markers, wet processing, discriminant analysis

\section{Introduction}

In recent years, due to the growing market for quality coffee, producers have sought for cultivars with features that meet the standard of quality expected. The challenge of breeders and researchers is to develop cultivars with desired agronomic characteristics and with a high-quality beverage (Bertrand et al., 2008).

The quality of the drink can be evaluated by the attributes of flavor and aroma produced during the roasting process from chemical compounds in the raw bean. The chemical composition of the beans can vary based on certain factors such as species, environment, processing, and drying, and also storage (Borém et al., 2016; Cheng et al., 2016; Clemente et al., 2015; Fassio et al., 2016). It is known that the genetic factor is one of the most important and that several compounds in the coffee bean are genetically controlled, such as caffeine, lipids, fatty acids, trigonelline, chlorogenic acid, sugar and proteins (Scholz et al., 2013; Taveira et al., 2014).

Some works have been developed to describe the chemical variability among genotypes of Coffea arabica using chemometric tools (Alonso-Salces et al., 2009; Garret et al., 2013; Kitzberger et al., 2013). The use of multivariate statistical methods, such as principal component analysis (PCA) and partial least-squares 
discriminant analysis (PLS-DA) allows the classification and discrimination of the samples and the chemical markers responsible for discrimination can be discovered (Krastanov, 2010).

A recent study was conducted by Marquetti et al. (2016) in which was used the PLS-DA to evaluate the genotypic and geographic origin of the Arabica coffee. The authors concluded that the method is effective in discriminating samples by genotypic and geographical origin through chemical data.

A better understanding of the chemical composition of $C$. arabica genotypes may cause new challenges and motivate changes in the production chain. In addition, establishing chemical tags will help in genotypic identification of coffees, which has recently become a key component for the definition of the quality of the drink (Taveira et al., 2014).

Considering the importance of genetic variability in the quality of the coffee and that few studies are carried out in relation to genotypic discrimination through chemical data, it was proposed the use of a template created by PLS-DA method for sorting and discriminating genealogical groups of Arabica coffee as to the chemical composition of the beans.

\section{Method}

\subsection{Sampling, Location of Experiment and Processing}

The experiment was developed in the agricultural year of 2016/2017 with samples of raw beans of 22 accessions of Coffea arabica divided into groups according to the genealogical origin (Table 1). The three groups are formed by genealogical accessions that stood out according to the score, showing final score higher than 82 points, according to protocols of the Specialty Coffee Association of America-SCAA.

Table 1. Coding, place of origin and identification of 22 accessions of C. arabica L., Active Germplasm Bank of Minas Gerais, evaluated in this study

\begin{tabular}{|c|c|c|c|}
\hline Genealogic Group & $\begin{array}{l}\text { Accession } \\
\text { Code } \\
\end{array}$ & Identification & Property and Place of Origin \\
\hline \multirow{10}{*}{ Bourbon (GB) } & MG0036 & Yellow Bourbon T8 & Fazenda Recreio, São Sebastião da Grama-SP \\
\hline & MG0016 & Red Bourbon & Fazenda São Domingos, Monte Santo-MG \\
\hline & MG0009 & Yellow Bourbon & Sítio São José, Dois Córregos-SP \\
\hline & MG0006 & Yellow Bourbon & Fazenda Santo Antônio, Araponga-MG \\
\hline & MG0011 & Red Bourbon & Fazenda São João Batista, Campos Altos-MG \\
\hline & MG0020 & Yellow Bourbon T7 & Fazenda Recreio, São Sebastião da Grama-SP \\
\hline & MG0041 & Yellow Bourbon T13 & Fazenda Recreio, São Sebastião da Grama-SP \\
\hline & MG0043 & Yellow Bourbon T15 & Fazenda Recreio, São Sebastião da Grama-SP \\
\hline & MG0064 & Red Bourbon & Fazenda Bela Vista, Guaranésia-SP \\
\hline & MG1206 & Red Bourbon & Fazenda dos Furtados, Três Pontas-MG \\
\hline \multirow{5}{*}{ Tymor Hybrid (HT) } & MG0277 & Tymor Hybrid UFV 376-52 & Experimental Area of Fundão, Epamig-Viçosa-MG \\
\hline & MG0289 & Tymor Hybrid UFV 376-01 & Experimental Area of Fundão, Epamig-Viçosa-MG \\
\hline & MG0357 & Tymor Hybrid UFV 441-04 & Experimental Area of Fundão, Epamig-Viçosa-MG \\
\hline & MG0303 & Tymor Hybrid UFV 427-09 & Experimental Area of Fundão, Epamig-Viçosa-MG \\
\hline & MG0278 & Tymor Hybrid UFV 376-37 & Experimental Area of Fundão, Epamig-Viçosa-MG \\
\hline \multirow{7}{*}{ Exotic Genotypes (GE) } & MG0625 & BE5 Wush-Wush UFV406-06 & Experimental Area of Fundão, Epamig-Viçosa-MG \\
\hline & MG0224 & Pacamara Paraná & Agronomical Institute of Paraná, Londrina-PR \\
\hline & MG0223 & Pacamara & Agronomical Institute of Paraná, Londrina-PR \\
\hline & MG0235 & Trifolia & Fazenda da Ilha, Alfenas-MG \\
\hline & MG0231 & Erecta & Fazenda da Ilha, Alfenas-MG \\
\hline & MG0228 & Laurina & Fazenda da Ilha, Alfenas-MG \\
\hline & MG1008 & Geisha $\times$ S288/23UFV328-29 & Experimental Area of Fundão, Epamig Viçosa-MG \\
\hline
\end{tabular}

The accessions assessed in the present study are deployed in the Active Bank of Germplasm of Coffea spp. of Minas Gerais, in a randomized blocks design with two replications and ten plants per plot, in the Experimental Field of Patrocínio of the Company of Farming Research of Minas Gerais-EPAMIG, located at 18 $59^{\prime 2} 26^{\prime \prime}$ South latitude, $48^{\circ} 58^{\prime} 95^{\prime \prime}$ West longitude and 975 meters of altitude, in the region of Alto Paranaíba. 
Samples were collected selectively when most of the fruits were at the point of ideal ripeness (cherry) and processed by the wet method for obtaining pulped coffee beans (Figure 1), and then were dried until reaching a water content of $11 \%$ (b.u.). After drying and processed, the samples were frozen in liquid nitrogen and ground using IKA A11 Basic Analytic ${ }^{\circledR}$ mill, sprayed and kept at $-80^{\circ} \mathrm{C}$ for further analysis of chemical compounds.

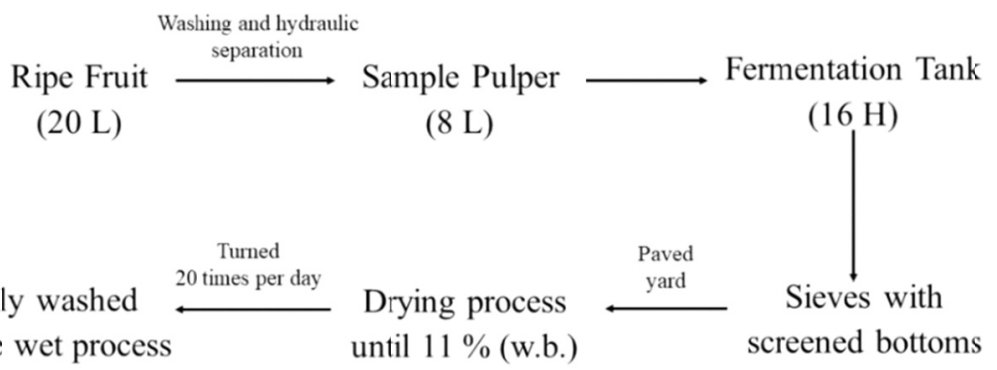

Figure 1. Wet processing flowchart adopted for the 22 accessions of $C$. arabica

\subsection{Chemical Analyses}

The levels of protein, lipids, total sugars, polyphenols, sucrose, caffeine, and fatty acids were analyzed in raw beans of accessions since these compounds are considered key to the quality of the coffee (Cheng et al., 2016).

The protein content was determined by the Kjeldahl method cited by AOAC (2000), using $0.5 \mathrm{~g}$ of powdered sample at all for digestion. The same amount of sample was used for the determination of total lipids by Soxhlet method (AOAC, 2000). The total sugars in the coffee beans were extracted by the Antrona method and quantified by spectrophotometry, at a wavelength of $620 \mathrm{~nm}$, using a standard curve of anhydrous glucose, according to the method described by Dische (1962). The polyphenols were extracted with the methanol extractor $50 \%(\mathrm{~V} / \mathrm{V})$ and identified according to the Folin Denis method, described by AOAC (2000). The caffeine content was determined by spectrophotometry at a wavelength of $273 \mathrm{~nm}$, using an analytical caffeine curve, according to the method proposed by Li et al. (1990). All analyses were performed in triplicate and the data were expressed in $\mathrm{g} 100 \mathrm{~g}^{-1}$ (b.s).

Sucrose analysis was followed by that proposed by Murkovic and Derler (2006) with a duplicate for all samples. The liquid chromatograph used consisted of an LC-10AD pump (Shimadzu), RID-10A Refractive Index detector (Shimadzu), Rheodyne injection valve and Star 5.5 data acquisition system (Varian). The samples and standard solutions were analyzed in two columns in series: Nucleosil C18-5 $\mu \mathrm{m} 250 \mathrm{~mm}$ x $4.6 \mathrm{~mm}$ (Supelco) and Discovery HS F5 $150 \mathrm{~mm} \times 4.6 \mathrm{~mm}$ (Supelco). The mobile phase was Milli-Q water at room temperature and a flow rate of $1.0 \mathrm{~mL} \mathrm{m^{-1 }}$ and injection volume of $20 \mu \mathrm{L}$. The final sucrose content was expressed in $\mathrm{g} 100^{-1}$ (b.s.) based on the standard sucrose curve. (Supelco cas $n^{\circ} 57501$ ).

The fatty acid profile was determined by gas chromatography according to Christie (1989) with a duplicate for all samples. HP7820A gas chromatograph equipped with a flame ionization detector was used. The separation of the esters was performed in a column HP-INNOWAX (HP) $15 \mathrm{~cm} \times 0.25 \mathrm{~mm} \times 0.25 \mu \mathrm{m}$, with temperature gradient: $150{ }^{\circ} \mathrm{C}, 1 \mathrm{~min}, 7^{\circ} \mathrm{C} \mathrm{min}{ }^{-1}$ until reaching $240{ }^{\circ} \mathrm{C}$; injector (split of $1 / 50$ ) at $250{ }^{\circ} \mathrm{C}$ and detector at $260^{\circ} \mathrm{C}$. Hydrogen was used as a carrier gas with a flow of $3 \mathrm{~mL} \mathrm{~min}^{-1}$ and injection volume of $1.0 \mu \mathrm{L}$. The identification of the peaks was made by comparison with standards of methylated fatty acids mix C14-C22 (Supelco cat $\mathrm{n}^{\mathrm{o}}$

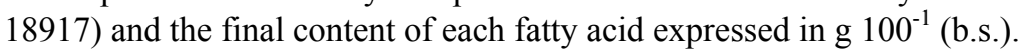

\subsection{Data Analysis}

The data from the chemical evaluations for the 22 accessions of $C$. arabica with two repetitions were analyzed by the principal components analysis (PCA) and partial-least squares discriminant analysis (PLS-DA) using the statistical software R (R-Development Core Team, 2017).

The PCA is an unsupervised multivariate method that aims to find new variables that are not correlated in such a way that they explain the maximum variation of the original data set $(\mathrm{X})$ without referring to any class label $(\mathrm{Y})$. These new variables are the main components and it is desirable that they are correlated with the original variables in order to reduce the original dimension of the variables in a smaller dimension of variables, consisting of the main components. In this sense, the PCA was used in order to evaluate the similarity between 
the chemical compounds, formed by matrix $\mathrm{X}$, in the different accession codes, as mentioned in sections 2.1 and 2.2 .

To classify the accession codes in the different genealogical groups, the partial-least squares discriminant analysis (PLS-DA) was used. Unlike the PCA, PLS-DA is a supervised method that uses the desired response (Y) to construct a model that classifies a sample by considering the variables of the matrix $\mathrm{X}$ and their respective category $(\mathrm{Y})$ to a given genealogical group. The method consists of modeling the structure of variance and covariances of latent variables in such a way as to maximize the multidimensional variance of the variables of matrix X in the direction of matrix Y. It is worth mentioning that due to the existence of a correlation between the chemical compounds, usual linear regression methods and conventional discriminant analysis (Linear Discriminant Analysis-LDA) would not be adequate (Taveira et al., 2014).

Given these specifications, the PLS-DA model was built to differentiate genealogical groups of $C$. arabica accessions with respect to chemical composition. To evaluate the performance of the model, the classification error rate for each PLS-DA component was considered. It was also used the load of each variable in the component that resulted in a better error rate to indicate the variables of matrix $\mathrm{X}$ that presented the greatest contributions with the PLS-DA component.

\section{Results and Discussion}

Two methods were used to evaluate and discriminate the accessions of the Active Germplasm Bank, processed by pulping, regarding the chemical composition of the raw beans, the unsupervised PCA method and the supervised PLS-DA classification method. For the first time, these analyses were applied together to discriminate genealogical groups of $C$. arabica regarding the chemical composition of the beans.

\subsection{Main Components Analysis}

The biplot was obtained according to the dispersion of the scores of the first main components in the axes, the first component being the one with the highest explained variance $(27.86 \%)$ and the second component the one with the lowest variance (20.91\%). The first two components explained together $48.77 \%$ of the total variation between the accessions in relation to the chemical parameters (Figure 2).

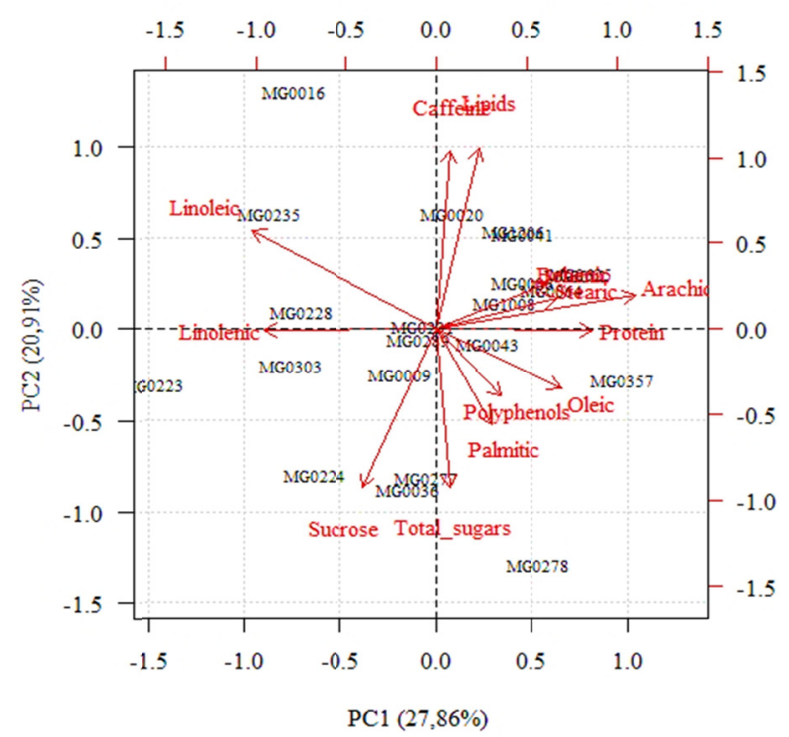

Figure 2. Biplot of the first two main components PC1 (27.86\%) and PC2 (20.91\%) for the data of the 22 accessions of $C$. arabica processed via wet process in relation to the chemical composition of the beans

The PC1 shows that there is a trend in the accessions MG0223, MG0303, and MG0228 to present a higher content of linolenic fatty acid and the accession MG0235 for linoleic fatty acid. For the accessions MG1008, MG0006, MG0064, MG0625 and MG0011 there is a tendency for the content of arachidic, stearic and behenic fatty acids and also for the content of protein in raw beans, as well as for the accessions MG0357 and MG0043 in relation to oleic fatty acid. For the PC2 values, it is noted that the accessions MG0278, MG0224, MG0036, MG0009 and MG0277 showed a tendency for higher sucrose and total sugar content, while the accessions 
MG1206, MG0020, MG0041 and MG0016 for caffeine content and total lipids. The MG0289 and MG0231 accessions showed intermediate values for all variables studied.

Therefore, most of the chemical variables contributed to the response of the analysis and it was possible to separate the accessions of pulped coffee. The variables polyphenols and palmitic acid presented the lowest contribution to the response of the analysis.

\subsection{Classification by Model PLS-DA}

The PCA provided an overview of the behavior of some accessions in relation to the content of chemical variables, but detailed information on the differences between genealogical groups was not obtained. Thus, the PLS-DA classification model was constructed to discriminate genealogical groups regarding the chemical composition of pulped coffee beans.

Figure 3A presents the projection of the samples of the accession codes in the 2 components of PLS-DA, given by the loads of the respective components of matrix X. It is observed that there was an overlap of genealogical groups, which indicates that there is a region in common among the accession codes, as can be seen in the $95 \%$ confidence ellipses in Figure 3A, and the greatest evidence of overlap can be verified for the exotic genotype group (GE). According to the PLS-DA model, the accession code is classified in the genealogical group with the highest load on the PLS-DA component with the best error rate (Figure 3D). Thus, Figure 4 shows the classifications resulting from the PLS-DA model and it is observed that it was not possible to discriminate the accessions MG0036 and MG0016 originally from the GB group, the accessions MG0303 and MG0289 originally from the HT group and MG0625 and MG1008 originally from the GE group (Figure 4 and Table 1). The accession codes that obtained the best correct classification rate were those classified in the GB genealogical group (27.9\%) followed by the HT group (52.22\%) since they presented the lowest error rate.

Figures $3 \mathrm{~B}$ and $3 \mathrm{C}$ (correlation chart and loads of variables in component 2 of PLS-DA) show the variables that most influenced the classification of the accessions in genealogical groups. The variables caffeine, stearic, arachidic and behenic fatty acids and the total lipid content influenced more in the classification of the bourbon group (GB). The group of exotic accessions (GE) was influenced by the variables sucrose, linolenic acid, linoleic acid, and protein content. The Tymor Hybrid group (HT) was classified by the variables polyphenols, total sugars and by the palmitic and oleic fatty acids.

The PCA identified the trends of most of the accessions evaluated in relation to practically all variables, except for polyphenols and palmitic acid. The chemical compounds present in raw coffee beans are important precursors of flavor and aroma produced during roasting. Genetic variability affects both the chemical composition and the physical characteristics of coffee beans, and these in turn directly influence the sensory quality of the beverage (Scholz et al., 2011; Borém et al., 2016). Therefore, identifying the behavior of the different genotypes of Arabica coffee in terms of chemical composition is a relevant element for the development of new cultivars with potential for specialty coffee production.

To verify and validate the model created, the error rate of classification was used (Figure 3D) and the lowest error rate was found for component $2(41.73 \%)$. The error rate was obtained by cross-validation procedure using 5 parts (5-fold) of the data set to adjust the model and the rest to test it in 100 simulations.

Five accesses had a strong tendency to higher levels of arachidic (C20:0) fatty acids (Figure 3), stearic (C18:0) and behenic (C22:0), and of these accessions, 3 are Bourbon. All these fatty acids are saturated with a long chain, and a previous study shows that the balance of flavor and aroma of foods are related to high levels of saturated fatty acids (Bertrand et al., 2008). Corroborating this study, Figueiredo et al. (2015) through analysis of main components, identified arachidic and stearic fatty acids as important for the genotypes of Bourbon with higher sensory scores.

Within each genealogical group, it is possible to identify the accessions highlighted for these variables. The accessions MG0223 for the group of Exotic accessions (GE), the accessions MG0277, MG0278 and MG0357 for the Tymor Hybrid group (HT) and the accessions MG0016 and MG0020 for the Bourbon group (GB), which were correctly classified by the PLS-DA model and remained more distant from the region in common of the groups, as can be seen in the comparison of Figures $3 \mathrm{~A}$ and 4.

It was observed that 2 samples from the GB group were classified by the PLS-DA model as being from the GE and HT genealogical groups, 2 samples from the GE group as being from the GB genealogical group, and two samples from the HT group as being from the GB and GE groups (Table 2). Thus, the diagonal formed by the values $8,5,3$ are the correct classifications of the model. In order to evaluate the generalization power of the 
PLS-DA model, it was submitted to a cross-validation procedure using 5 parts (5-fold) of the data set to adjust the model and the rest to test it in 100 simulations.

A

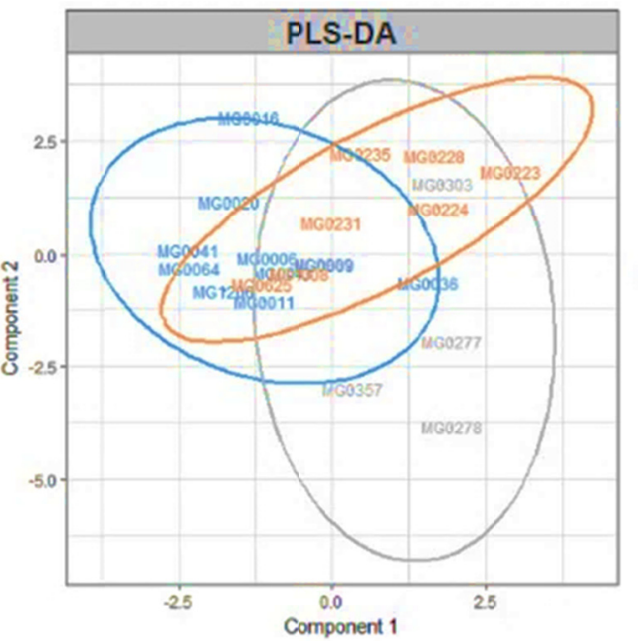

C

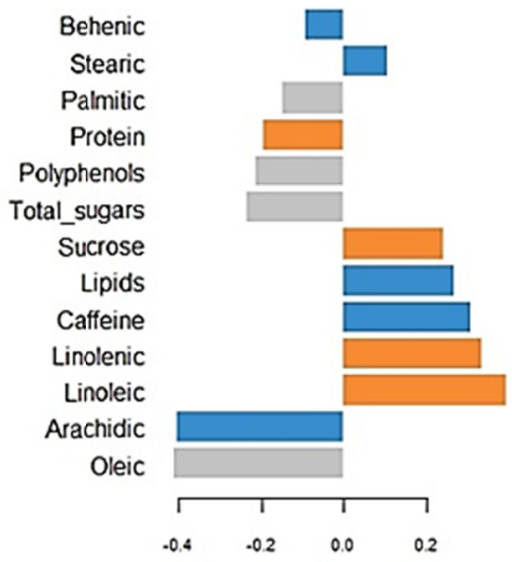

B

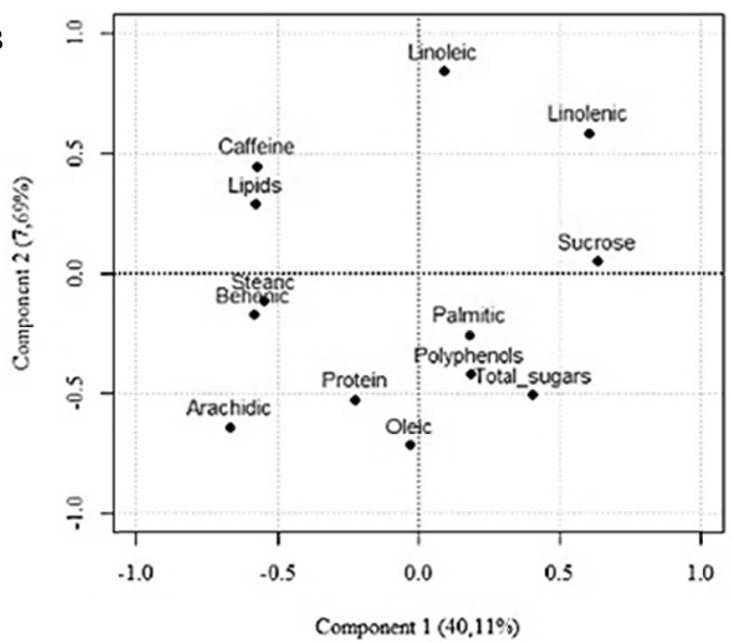

D

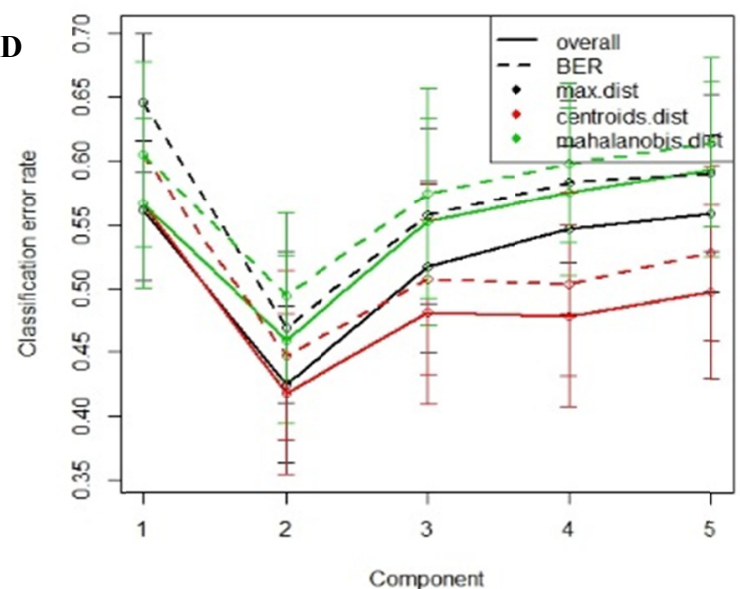

Figure 3. PLS-DA (A) scores of two components for the chemical composition that differentiates genealogical groups. (GB) Bourbon Group, (GE) Exotic Group and (HT) Tymor Hybrid Group. (B) Correlation of chemical compounds with components 1 and 2 with classes GB, GE, and HT. (C) Loads of component 2 of the PLS-DA model of chemical compounds for each genealogical group. (D) The error rate of classification generated for the components of the PLS-DA model by means of cross-validation procedure using 5 parts (5-fold) of the data set to adjust the model and the rest to test it in 100 simulations 


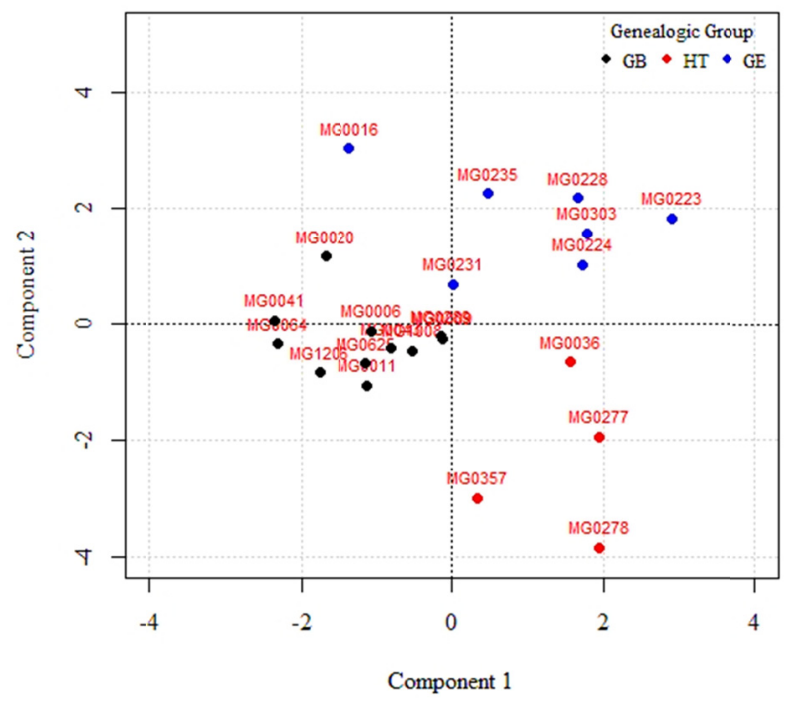

Figure 4. PLS-DA scores of two components for the chemical composition with the classifications of genealogical groups. - (GB) Bourbon group, $\bullet$ (HT) Timor Hybrid group and $\bullet$ (GE) Exotic group

Table 2. False positive and negative counts with reference to the classification of genealogical groups by the PLS-DA model and their respective error rates obtained by cross-validation procedure using 5 parts ( 5 -fold) of the data set to adjust the model and the rest to test the model in 100 simulations

\begin{tabular}{|c|c|c|c|c|}
\hline \multirow{2}{*}{ Genealogic Group } & \multicolumn{3}{|c|}{ Classified by the PLS-DA model } & \multirow{2}{*}{ Total } \\
\hline & GB* & GE* & $\mathrm{HT}^{*}$ & \\
\hline GB* & 8 & 1 & 1 & 10 \\
\hline GE* & 2 & 5 & 0 & 7 \\
\hline $\mathrm{HT}^{*}$ & 1 & 1 & 3 & 5 \\
\hline Total & 11 & 7 & 4 & 22 \\
\hline Error rate classification & $27.90 \%$ & $54.00 \%$ & $52.22 \%$ & - \\
\hline Global error rate & $41.73 \%$ & - & - & - \\
\hline
\end{tabular}

Note. *GB: Bourbon Group; GE: Exotic Group; HT: Tymor Hybrid Group.

As it was an unsupervised analysis, the PCA was not sufficient to group the accessions according to their genealogical origin, based on chemical data. Therefore, the PLS-DA was required as a useful tool for this proposal.

The results of the PLS-DA model showed the variables that most influenced the classification of genealogical groups and, therefore, the possible chemical markers for the accessions processed by the pulped method were identified. The chemical markers involved with the beverage quality are important for the improvement of genetic improvement aimed at higher quality coffees.

As seen for the PCA trends, the PLS-DA model indicated arachidic, stearic and behenic fatty acids as the classifiers of the Bourbon group (GB), this demonstrates that these are important markers for this group. For the group of Exotic accessions (GE) the linolenic and linoleic fatty acids were the main markers and for the Tymor Hybrid group (HT) the palmitic and oleic fatty acids. The Tymor Hybrid germplasm comes from the natural crossing between C. arabica and C. canephora, and the introgression of the genes of C. canephora increases the oleic fatty acid content in raw Arabica coffee beans (Alves et al., 2003).

Caffeine content has been widely used to differentiate genotypes (Alonso-Salces et al., 2009; Figueiredo et al., 2013; Fassio et al., 2016), mainly due to the high level of coffee seeds and for varying according to species and variety (Teixeira et al., 2012). Caffeine was identified as a possible marker for the Bourbon group (GB), a fact also observed by Taveira et al. (2014) and Figueiredo et al. (2013).

Polyphenol content was also identified by the PLS-DA model as a possible marker for the Tymor Hybrid group. This result confirms the elucidation in the literature that the background of $C$. canephora increases the levels of polyphenols in Arabica coffees (Bertrand et al., 2008; Alonso-Salces et al., 2009; Garret et al., 2013). 
Sucrose is an important precursor of chemical compounds responsible for the taste and aroma of the beverage (Cheng et al., 2016). The content of this sugar may vary depending on the species, environment, and processing. According to Knopp et al. (2006), the consumption of sugars under anaerobic conditions is very high when compared to aerobic conditions for the production of the same amount of energy. Therefore, the levels of total and non-reducing sugars may vary according to the type of processing adopted (Taveira et al., 2015). In this study, as the environmental conditions and the type of processing were standardized, the differences in sugar content are due to the cultivar and, therefore, the level of sucrose is higher for exotic accessions.

The PLS-DA model created was able to classify the majority of the accessions of the Bourbon (GB), Exotic (GE) and Tymor Hybrid (HT) groups correctly. The Bourbon group was the one that presented the best classification by the created model, this confirms the stability of this germplasm in relation to the chemical composition of the grains and consequently to the beverage quality.

Several studies are developed with the aim of identifying the most promising genetic materials for obtaining specialty coffees (Scholz et al., 2013; Gimase et al., 2014; Carvalho et al., 2016; Kitzberger et al., 2016; Sobreira et al., 2016). The identification of the outstanding accessions for each genealogical group demonstrates which are the accessions with greater stability of chemical compounds and consequently more promising for the production of special beans, within the Active Germplasm Bank of Minas Gerais.

\section{Conclusions}

The PLS-DA classification method is effective in discriminating genealogical groups in terms of the chemical composition of beans.

The good classification of genealogical groups determines the identification of important chemical markers for accessions processed by the wet method.

The identification of chemical markers in studies with Arabica coffee genotypes is an approach that can be used to enrich genetic improvement works aimed at beverage quality.

\section{Acknowledgements}

The authors thank the Consórcio Pesquisa Café, the FAPEMIG, the CNPq, the CAPES by financed this work, and the Empresa de Pesquisa Agropecuária de Minas Gerais and the Universidade Federal de Lavras for the support.

\section{References}

Alonso-Salces, R. M., Serra, F., Reniero, F., \& Héberger, K. (2009). Botanical and geographical characterization of green coffee (Coffea arabica and Coffea canephora): Chemometric evaluation of phenolic and methylxanthine contents. Journal of Agricultural and Food Chemistry, 57, 4224-4235. https://doi.org/ 10.1021/jf8037117

Alves, M. R., Casal, S., Oliveira, M. B. P. P., \& Ferreira, M. A. (2003). Contribution of FA profile obtained by high-resolution $\mathrm{GC} /$ chemometric techniques to the authenticity of green and roasted coffee varieties. Journal of the America Oil Chemist's Society, 80, 511-517. https://doi.org/10.1007/s11746-003-0730-0

AOAC (Association of Official Agriculture Chemists). (2000). Official methods of the Association of the Agricultural Chemists (15th ed.). Washington: DC.

Bertrand, B., Villarreal, D., Laffargue, A., Posada, H., Lashermes, P., \& Dussert, S. (2008). Comparison of the effectiveness of fatty acids, chlorogenic acids, and elements for the chemometric discrimination of coffee (Coffea Arabica L.) varieties and growing origins. Journal of Agricultural and Food Chemistry, 56, 2273-2280. https://doi.org/10.1021/jf073314f

Borém, F. M., Figueiredo, L. P., Ribeiro, F. C., Taveira, J. H. S., Giomo, G. S., \& Salva, T. J. (2016). The relationship between organic acids, sucrose and the quality of specialty coffees. African Journal of Agriculture Research, 11, 709-717. https://doi.org/10.5897/AJAR2015.10569

Carvalho, A. M., Rezende, J. C., Rezende, T. T., Ferreira, A. D., Rezende, R. M., Mendes, A. N. G., \& Carvalho, G. R. (2016). Relationship between the sensory attributes and the quality of coffee in different environments. African Journal of Agricultural Research, 11, 3607-3614. https://doi.org/10.5897/AJAR2016.11545

Cheng, B., Furtado, A., Smyth, H. E., \& Henry, R. J. (2016). Influence of genotype and environment on coffee quality. Trends in Food Science \& Technology, 57, 20-30. https://doi.org/10.1016/j.tifs.2016.09.003

Christie, W. W. (1989). Gas chromatography and lipids. Oxford: Pergamon. 
Clemente, A. C. S., Cirillo, M. A, Malta, M. R., Caixeta, F., Pereira, C. C., \& Rosa, S. D. V. F. (2015). Post-harvest operations and physicochemical and sensory quality of coffees. Coffee Science, 10(2), 233-241.

Dische, Z. (1962). General color reactions. In R. L. Whistler, \& M. L. Wolfram (Eds.), Carbohydrate chemistry. New York: Academic Press.

Fassio, L. O., Malta, M. R., Carvalho, G. R., Liska, G. R., Lima, P. M., \& Pimenta, C. J. (2016). Sensory description of cultivars (Coffea arabica L.) resistant to rust and its correlation with caffeine, trigonelline, and chlorogenic acid compounds. Beverages, 2, 1-12. https://doi.org/10.3390/beverages2010001

Figueiredo, L. P., Borém, F. M., Ribeiro, F. C., Giomo, G. S., \& Taveira, J. H. S. (2015). Fatty acid profile and parameters of quality of specialty coffees produced in different Brazilian regions. African Journal of Agricultural Research, 10, 3484-3493. https://doi.org/10.5897/AJAR2015.9697

Figueiredo, L. P., Borém, F., Cirillo, M., Ribeiro, F. C., Giomo, G. S., \& Salva T. J. (2013). The Potential for High-Quality Bourbon Coffees From Different Environments. Journal of Agricultural Science, 5, 87-98. https://doi.org/10.5539/jas.v5n10p87

Garret, R., Schmidt, E. M., Pereira, L. F. P., Kitzberger, C. S. G., Scholz, M. B. S., Eberlin, M. N., \& Rezende, C. M. (2013). Discrimination of arabica coffee cultivars by electrospray ionization Fourier transform ion cyclotron resonance mass spectrometry and chemometrics. LWT-Food Science and Technology, 50, 496-502. https://doi.org/10.1016/j.lwt.2012.08.016

Gimase, J. M., Thagana, W. M., Kirubi, D. T., Gichuru, E. K., \& Kathurima, C. W. (2014). Beverage quality and biochemical attributes of arabusta coffee (C. arabica L. $\times$ C. canephora Pierre) and their parental genotypes. African Journal of Food Science, 8, 456-464. https://doi.org/10.5897/AJFS2014.1132

Kitzberger, C. S. G., Scholz, M. B. S., Pereira, L. F. P., \& Benassi, M. T. (2013). Composição química de cafés arábica de cultivares tradicionais e modernas. Pesquisa Agropecuária Brasileira, 48, 1498-1506. https://doi.org/10.1590/S0100-204X2013001100011

Kitzberger, C. S. G., Scholz, M. B. S., Pereira, L. F. P., Silva, J. B. G. D., \& Benassi, M. T. (2016). Profile of the diterpenes, lipid and protein content of different coffee cultivars of three consecutive crops. AIMS Agriculture and Food, 1, 254-264. https://doi.org/10.3934/agrfood.2016.3.254

Knopp, S., Bytof, G., \& Selmar, D. (2006). Influence of processing on the content of sugars in green Arabica coffee beans. European Food Research and Technology, 223, 195-201. https://doi.org/10.1007/ s00217-005-0172-1

Krastanov, A. (2010). Metabolomics-The state of art. Biotechnology \& Biotechnological Equipment, 24, 1537-1543. https://doi.org/10.2478/V10133-010-0001-Y

Li, S., Berger, J., \& Hartland, S. (1990). UV spectrophotometric determination of theobromine and caffeine in cocoa beans. Analytica Chimica Acta, 232, 409-412. https://doi.org/10.1016/S0003-2670(00)81263-5

Marquetti, I., Linka, J. V., Lemes, A. L. G., Scholz, M. B. S., Valderrama, P., \& Bona, E. (2016). Partial least square with discriminant analysis and near-infrared spectroscopy for evaluation of geographic and genotypic origin of arabica coffee. Computers and Electronics in Agriculture, 121, 313-319. https://doi.org/ 10.1016/j.compag.2015.12.018

Murkovic, M., \& Derler, K. (2006). Analysis of amino acids and carbohydrates in green coffee. Journal of Biochemical and Biophysical Methods, 69, 25-32. https://doi.org/10.1016/j.jbbm.2006.02.001

R Delopment Core Team. (2017). R: A language and environment for statistical computing. Foundation for Statistical Computing, Viena. Retrieved from http://www.R-project.org

Scholz, M. B. S., Figueiredo, V. R. G., Silva, J. V. N., \& Kitzberger, C. S. G. (2011). Características físico-químicas de grãos verdes e torrados de cultivares de café (Coffea arabica L.) do IAPAR. Coffee Science, 6(3), 245-255.

Scholz, M. B. S., Silva, J. V. N., Figueiredo, V. R. G., \& Kitzberger, C. S. G. (2013). Atributos sensoriais e características físico-químicas de bebida de cultivares de café do IAPAR. Coffee Science, 8, 6-16.

Sobreira, F. M., Oliveira, A. C. B., Pereira, A. A., Garçoni, A. M., \& Sakiyama, N. S. (2016). Divergence among arabica coffee genotypes for sensory quality. Australian Journal of Crop Science, 10, 1442-1448. https://doi.org/10.21475/ajcs.2016.10.10.p7430 
Taveira, J. H. S., Borém, F. M., Figueiredo, L. P., Reis, N., Franca, A. S., Harding, S. A., \& Tsai, C. J. (2014). Potential markers of coffee genotypes grown in different Brazilian regions: A metabolomics approach. Food Research International, 61, 75-82. https://doi.org/10.1016/j.foodres.2014.02.048

Taveira, J. H. S., Borém, F. M., Rosa, S. D. V. F., Oliveira, P. D., Giomo, G. S., Isquierdo, E. P., \& Fortunato, V. A. (2015). Post-harvest effects on beverage quality and physiological performance of coffee beans. African Journal of Agricultural Research, 10, 1457-1466. https://doi.org/10.5897/AJAR2014.9263

Teixeira, A. L., Prado, P. E. R., Dias, K. O. G., Malta, M. R., \& Gonçalves, F. M. A. (2012). Avaliação do teor de cafeína em folhas e grãos de acessos de café Arábica. Revista Ciência Agronômica, 43, 129-137.

\section{Copyrights}

Copyright for this article is retained by the author(s), with first publication rights granted to the journal.

This is an open-access article distributed under the terms and conditions of the Creative Commons Attribution license (http://creativecommons.org/licenses/by/4.0/). 